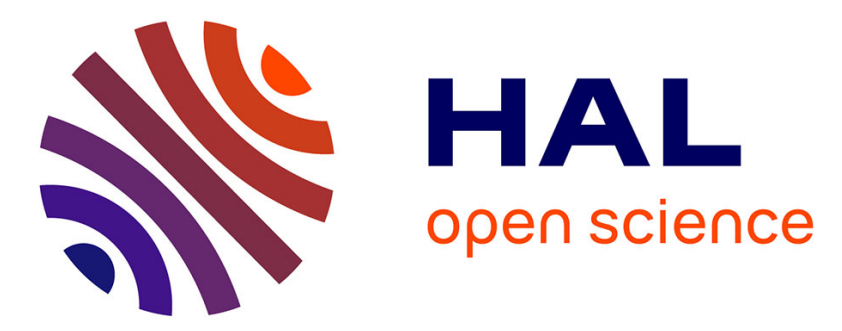

\title{
Helicobacter pylori urease and flagellin alter mucin gene expression in human gastric cancer cells
}

Michael Perrais, Christel Rousseaux, Marie-Paule Ducourouble, René Courcol, Pascal Vincent, Nicolas Jonckheere, Isabelle van Seuningen

\section{To cite this version:}

Michael Perrais, Christel Rousseaux, Marie-Paule Ducourouble, René Courcol, Pascal Vincent, et al.. Helicobacter pylori urease and flagellin alter mucin gene expression in human gastric cancer cells. Gastric Cancer, 2014, 17, pp.235-246. 10.1007/s10120-013-0267-5 . hal-02905802

\section{HAL Id: hal-02905802 \\ https://hal.science/hal-02905802}

Submitted on 6 Oct 2020

HAL is a multi-disciplinary open access archive for the deposit and dissemination of scientific research documents, whether they are published or not. The documents may come from teaching and research institutions in France or abroad, or from public or private research centers.
L'archive ouverte pluridisciplinaire HAL, est destinée au dépôt et à la diffusion de documents scientifiques de niveau recherche, publiés ou non, émanant des établissements d'enseignement et de recherche français ou étrangers, des laboratoires publics ou privés.

\section{(ㄷ)(1) $\$$}

Distributed under a Creative Commons Attribution - NonCommerciall 4.0 International 


\section{Gastric Cancer}

\section{Helicobacter pylori urease and flagellin alter mucin gene expression in human gastric cancer cells \\ --Manuscript Draft--}

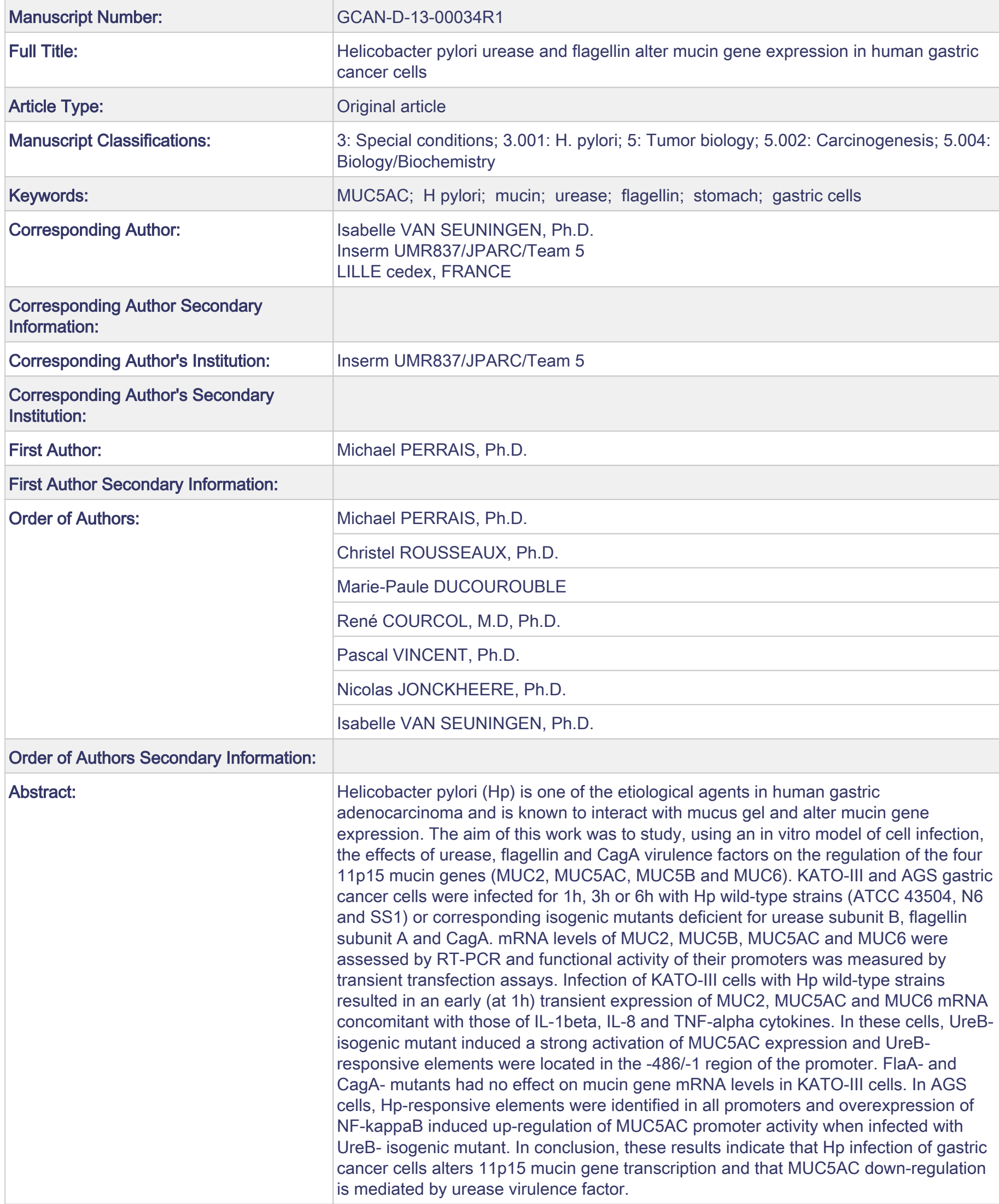




\section{Helicobacter pylori urease and flagellin}

alter mucin gene expression in human gastric cancer cells

Michaël Perrais ${ }^{\mathrm{a}^{*}}$, Christel Rousseaux ${ }^{\mathrm{b}^{*}}$, Marie-Paule Ducourouble ${ }^{\mathrm{a}}$, René Courcol $^{\mathrm{b}}$, Pascal Vincent $^{\mathrm{b}}$, Nicolas Jonckheere ${ }^{\mathrm{a}}$, and Isabelle Van Seuningen ${ }^{\mathrm{a}}$

anserm, UMR837, JPARC, Team «Mucins, epithelial differentiation and Carcinogenesis », Rue Polonovski, F-59045 Lille cedex, France

bInserm, E9919, Université JE 2225, Institut de Biologie de Lille, F-59021 Lille, France

* Equal participation of the two authors

Type of article: original article

Short title: Transcriptional regulation of MUC5AC by Helicobacter pylori

Word count: 3997

To whom correspondence should be sent:

Isabelle Van Seuningen, $\mathrm{PhD}$

Inserm UMR837, JPARC, Team "Mucins, epithelial differentiation and carcinogenesis"

Bâtiment G. Biserte,

Rue Polonovski,

59045 Lille cedex, France

Phone: +33.320.29.88.67, FAX: +33.320.53.85.62

E-mail: isabelle.vanseuningen@inserm.fr 
Abbreviations

bp: basepair

Fla: Flagellin

Hp: Helicobacter pylori

IL: Interleukin

$N F-\kappa B$ : Nuclear factor $-\kappa B$

PCR: Polymerase chain reaction

RT: Reverse transcriptase

TNF- $\alpha$ : Tumor necrosis factor- $\alpha$

Ure: Urease

CagA: Cytotoxin Associated Antigen 


\begin{abstract}
Background: Helicobacter pylori $(\mathrm{Hp})$ is one of the etiological agents in human gastric adenocarcinoma and is known to interact with mucus gel and alter mucin gene expression. The aim of this work was to study, using an in vitro model of cell infection, the effects of urease, flagellin and CagA virulence factors on the regulation of the four 11p15 mucin genes (MUC2, MUC5AC, MUC5B and MUC6). Methods: KATO-III and AGS gastric cancer cells were infected for 1h, 3h or 6h with Hp wild-type strains (ATCC 43504, N6 and SS1) or corresponding isogenic mutants deficient for urease subunit B, flagellin subunit A and CagA. mRNA levels of MUC2, MUC5B, MUC5AC and MUC6 were assessed by RT-PCR and functional activity of their promoters was measured by transient transfection assays. Results: Infection of KATO-III cells with Hp wild-type strains resulted in an early (at $1 \mathrm{~h}$ ) transient expression of $M U C 2, M U C 5 A C$ and $M U C 6$ mRNA concomitant with those of IL$1 \beta$, IL-8 and TNF- $\alpha$ cytokines. In these cells, $\mathrm{UreB}^{-}$isogenic mutant induced a strong activation of MUC5AC expression and UreB-responsive elements were located in the $-486 /-1$ region of the promoter. $\mathrm{FlaA}^{-}$and $\mathrm{CagA}^{-}$mutants had no effect on mucin gene mRNA levels in KATO-III cells. In AGS cells, Hp-responsive elements were identified in all promoters and overexpression of NF- $\kappa \mathrm{B}$ induced up-regulation of $M U C 5 A C$ promoter activity when infected with $\mathrm{UreB}^{-}$isogenic mutant. Conclusion: these results indicate that Hp infection of gastric cancer cells alters $11 \mathrm{p} 15$ mucin gene transcription and that $M U C 5 A C$ down-regulation is mediated by urease virulence factor.
\end{abstract}

Keywords: MUC5AC, H pylori, mucin, urease, stomach 


\section{Introduction}

Gastric cancer is the second common cancer in humans worldwide. In 1994, the International Agency for Research on Cancer recognized Helicobacter pylori (Hp), a Gram negative bacterium, which natural habitat is restricted to the stomach, as one of the etiological agents in human gastric adenocarcinoma and as a type I carcinogenetic agent [1-3]. Indeed, epidemiological studies performed in different countries have shown a correlation between gastric cancer rate and $\mathrm{Hp}$ seroprevalence in populations [4].

As the major glycoprotein component of mucus, mucins play a major role in maintaining mucosae integrity $[5,6]$. The genes encoding mucins are now classified in two families, the large secreted gel-forming mucins and the membrane-bound mucins [7, 8]. In normal stomach, MUC1 and MUC5AC are the main mucin genes expressed in surface/foveolar epithelial cells whereas MUC6 is expressed in the antral glands [9, 10]. During infection, Hp associates with the mucus layer [11], interacts with MUC5AC [12-14] and binds gastric epithelial cells [15]. In Hp-induced gastritis, the pattern of mucin gene expression is altered [16] and is characterized by an aberrant expression of the gland-type gastric mucin MUC6 and a decreased expression of the normal surface-type mucin MUC5AC in the surface epithelium $[9,10,16-19]$. However, until now nothing is known about the intracellular molecular mechanisms responsible for MUC5AC altered profile of expression. MUC5AC being the major secreted mucin in stomach with an altered profile of expression during $\mathrm{Hp}$ infection, we undertook to decipher the molecular mechanisms responsible for MUC5AC transcriptional regulation by Hp.

Since the discovery of $\mathrm{Hp}$ and its involvement in gastric pathologies, many studies have been conducted to identify determinants of bacterial pathogenicity. Among Hp attributes, urease and flagellin have been recognized as essential for bacterial colonization of the gastric mucosa $[20,21]$. Urease degrades urea into ammonia and carbon dioxide and provides an 
acid-neutralizing cloud of ammonia that could protect the bacterium from gastric acidity. Flagella (5 to 7 per cell), which confer motility, are made of polymers of two subunits, the major flagellin FlaA and the minor flagellin FlaB. The cagA gene is one of the 31 genes of the pathogenicity island cag ( $c a g$ PAI), which encodes a type IV secretion system allowing the translocation of CagA into the gastric epithelial cells. CagA modifies the phosphorylation pattern of intracellular proteins leading to the cytoskeleton rearrangement of infected cells [22].

To better understand $\mathrm{Hp}$-induced molecular mechanisms associated with altered expression of secreted mucins and especially MUC5AC in the gastric mucosa, we undertook to study the transcriptional regulation of these genes using an in vitro model of epithelial gastric cell infection by $\mathrm{Hp}$ in which the impact of urease, flagellin and CagA $\mathrm{Hp}$ virulence factors on the regulation of the mucin genes was studied at the transcriptional level. In this report, we establish a direct link between $\mathrm{Hp}$ infection of gastric cancer cells and downregulation of $M U C 5 A C$ gene expression by the urease virulence factor. 


\section{Materials and methods}

\section{Cell lines}

KATO-III and AGS human gastric adenocarcinomatous cell lines were cultured as previously described [23].

\section{Bacterial strains}

The Helicobacter pylori wild type strain ATCC 43504, the parental strain N6 [24], N6 flaA $\Omega \mathrm{Km}$ (flagellin (FlaA)-deficient [25]) and N6 ureB :: Tn3Km (urease (UreB)-deficient [24]) mutants, the parental strain SS1 and the deficient mutant SS1 $\mathrm{CagA}^{-}$(SS1 cag $\Omega \mathrm{Km}$ ) $[26,27]$ were a kind gift of Dr. A. Labigne (Institut Pasteur, Pathogénie bactérienne des muqueuses, Paris). Bacteria were grown on Columbia agar (Becton Dickinson) supplemented with $0.5 \%$ glucose, $0.05 \%$ cystein chlorhydrate and $10 \%$ horse blood. Plates were incubated for $48 \mathrm{~h}$ in $5 \% \mathrm{O}_{2}$ and $11 \% \mathrm{CO}_{2}$.

\section{Infection of cell monolayers}

Forty-eight hour cultures of $\mathrm{Hp}$ on agar plates were swabbed and bacteria were immediately suspended in $0.85 \% \mathrm{NaCl}$ at $6.2 \mathrm{Mc}$ Farland unit density $\left(\underline{10^{9}}\right.$ viable bacteria per $\underline{\mathrm{ml}})$. One $\mathrm{ml}$ of this bacterial suspension was added to cell cultures and infected cells were placed at $37^{\circ} \mathrm{C}$ in a $5 \%$ to $10 \% \mathrm{CO}_{2}$ and $80-90 \%$ air atmosphere incubator. Cells were incubated with bacteria up to $24 \mathrm{~h}$. No antibiotics were added to the co-culture. Cellular integrity, determined by measuring the amount of lactate dehydrogenase in the culture medium using Olympus System Reagent Kit, was performed after 24h cell infection.

\section{RT-PCR}

Cells were harvested at confluence and total RNA $(1.5 \mu \mathrm{g})$, extracted with the Qiamp RNA blood mini-kit (Qiagen), was used to prepare cDNA using the Advantage TM RT-forPCR kit (Clontech). PCRs on $5 \mu 1$ of cDNA using specific pairs of primers for the mucin genes and analyses of PCR products were performed as described before [23, 28, 29]. Primers 
used to study the expression of IL- $1 \beta$, IL-6, IL-8, TNF- $\alpha$ and NF- $\kappa$ B p65 subunit are indicated in table I. 18S rRNA subunit was used as an internal control. The gene of interest/18S ratio was calculated by densitometric analysis of the DNA bands using the Gel Analyst Gel Smart software (ClaraVision, Paris, France). All PCR studies were performed in triplicate on samples from three different sets of experiments.

\section{Plasmid constructions}

MUC2 (-2627/-1 and -2096/+27), MUC5AC (-1366/-1, $-486 /-1$ and -202/-1), and MUC5B (-223/-1, -1329/-1117 and -2044/-1117) promoter deletion mutants were previously described [23, 28, 29]. Plasmids used for transfection studies were prepared using the Endofree plasmid Mega kit (Qiagen).

\section{Transient transfection assays}

Cell transfections with pGL3 deletion mutants of $M U C 2, M U C 5 A C, M U C 5 B$ and $m M u c 5 a c$ promoters were performed using Effectene ${ }^{\circledR}$ reagent (Qiagen) as previously described [28]. Briefly, cells $\left(0.5 \times 10^{6}\right.$ cells/well in a 6-well plate $)$ were passed the day before the transfection. Transfected cells were then left for another $24 \mathrm{~h}$ incubation at $37^{\circ} \mathrm{C}$. Infection with $\mathrm{Hp}$ strains $\left(10^{9} \mathrm{cfu} / \mathrm{ml}\right)$ was carried out $1 \mathrm{~h}, 3 \mathrm{~h}$, or $6 \mathrm{~h}$ before cell harvesting. Total cell extract preparation, luciferase activity and protein content measurement (BCA kit, Pierce) were carried out as previously described [28]. Each plasmid was assayed in triplicate in at least three separate experiments. Co-transfection studies were performed in the same conditions in the presence of $1 \mu \mathrm{g}$ of the pGL3-deletion mutant and $0.25 \mu \mathrm{g}$ of the pCMV4NF- $\kappa \mathrm{B}$ p65 expression vector. Empty pCMV4 vector was used as the reference.

\section{Statistics}

The statistical analyses were carried out using both Excel and GraphPad 4.0 softwares (GraphPad softwares Inc., La Jolla, USA). The differences in the means of samples were analyzed using student $t$ test or one way anova test with selected comparison using tukey post 
hoc test with differences less than 0.05 considered as statistically significant $(*)$. ** indicates $\mathrm{p}<0.01$ and $* * * \mathrm{p}<0.001$ 


\section{Results}

\section{Influence of Hp virulence factors on mucin gene mRNA levels in gastric cancer cells}

When KATO-III cells were infected with the wild-type strains, no effect was observed on $M U C 5 B$ mRNA levels whereas $M U C 2, M U C 5 A C$ and MUC6 expression noticeably increased at $1 \mathrm{~h}$ infection (Fig.1). This effect was transient as it was not maintained at $3 \mathrm{~h}$ or $6 \mathrm{~h}$ infection. More interestingly, infection with the $\mathrm{UreB}^{-}$mutant resulted in a strong increase of MUC5AC expression at $1 \mathrm{~h}$ (7-fold) when compared with the cells infected with N6 wild-type strain. MUC2, MUC5B and MUC6 mRNA levels were not affected by the $\mathrm{UreB}^{-}$mutant. Infection with $\mathrm{FlaA}^{-}$or $\mathrm{CagA}^{-}$mutants had no additional impact on the expression of the four 11 p15 mucin genes when compared with the respective wild-type strains. In AGS cells, no effect was seen on mucin gene expression (not shown). In conclusion, a transient upregulation of $M U C 2, M U C 5 A C$ and $M U C 6$ mucin genes was observed in KATO-III cells at 1h infection with the three Hp wild-type strains. This effect was dramatically enhanced for MUC5AC after infection with $\mathrm{UreB}^{-}$isogenic mutant.

\section{Influence of $\mathrm{Hp}$ and UreB, FlaA and CagA virulence factors on $M U C 2$ promoter activity}

Having shown that mucin gene mRNA levels were altered after Hp infection, we undertook to study the effect of Hp at the promoter level and identify Hp-responsive regions. In KATO-III cells, wild-type strain ATCC 43504 increased luciferase activity of the 2096/+27 region of MUC2 promoter (2 fold) (Fig. 2). N6 wild-type strain and UreB- and FlaA $^{-}$isogenic mutants had little effect on $M U C 2$ promoter activity. Absence of CagA increased activity ( 2 fold) of the $-2627 /-1$ fragment whereas it decreased that of the $-2627 /-1$ promoter region. In AGS cells, activation of the -2627/-1 MUC2 promoter region was observed with the three wild-type strains at $3 \mathrm{~h}$ infection followed by a $50 \%$ inhibition at $6 \mathrm{~h}$ (Fig. 3). This activation was lost with fragment -2096/+27. Isogenic mutant UreB- had no 
effect whereas FlaA ${ }^{-}$enhanced activity of the fragment $-2627 /-1$ at $1 \mathrm{~h}$ ( 2 fold $)$. Infection with $\mathrm{CagA}^{-}$mutant resulted in a two-fold activation of the two fragments. Altogether these results indicate that $M U C 2$ promoter contains positive and negative regulatory elements to $\mathrm{Hp}$ virulence factors that show cell-specific activity.

\section{Influence of $\mathrm{Hp}$ and UreB, FlaA and CagA virulence factors on $M U C 5 A C$ promoter activity}

In KATO-III cells, Hp wild-type strains ATCC 43504 and N6 induced a time-dependent inhibition of the $-202 /-1$ MUC5AC promoter region resulting in at least $50 \%$ loss at $6 \mathrm{~h}$ infection (Fig. 3). This inhibition was lost with the $-1366 /-1$ region of the promoter. Infection with wild-type strain SS1 induced the activity of the fragment $-486 /-1$ in a time-dependent manner. Activation of the $-486 /-1$ deletion mutant was found after cell infection with UreB $^{-}$at 3h (2.2 fold), with $\mathrm{FlaA}^{-}$at $6 \mathrm{~h}$ (2 fold) and with $\mathrm{CagA}^{-}$at $6 \mathrm{~h}$ (1.6 fold). The activation by $\mathrm{UreB}^{-}$was delayed at $6 \mathrm{~h}$ post-infection with promoter fragment -202/-1. In AGS cells, the three wild-type strains induced activation of the $-202 /-1$ and of the $-1366 /-1$ promoter regions at $1 \mathrm{~h}$. Altogether, this indicates that cell-specific urease, flagellin, and CagA positive and negative elements are present within the MUC5AC promoter.

$\mathrm{UreB}^{-}$showed a transactivating effect of the $-1366 /-1$ fragment at $3 \mathrm{~h}$ ( 2 fold) that was inverted (inhibition of $75 \%$ ) when using the $-486 /-1$ promoter region. These results indicate that UreB responsive elements are present within the $-1366 /-203$ region of MUC5AC promoter. $\mathrm{FlaA}^{-}$had a strong transactivating effect on the $-486 /-1$ MUC5AC promoter region that was lost on the $-202 /-1$ region. This indicates that FlaA responsive elements are present within the $-486 /-203$ region of $M U C 5 A C$ promoter. Infection with $\mathrm{CagA}^{-}$deficient mutant resulted in transactivation of the $-202 /-1$ region, indicating that CagA responsive elements are located in that part of the promoter. 


\section{Influence of Hp and UreB, FlaA and CagA virulence factors on MUC5B promoter}

activity

Infection of KATO-III cells with ATCC 43504, N6 and SS1 wild-type strains decreased $M U C 5 B$ promoter activity in a time-dependent manner and resulted in 60-80\% inhibition of both promoters at $6 \mathrm{~h}$ infection (Fig. 4). The effect was different with $-2044 /-1117$ construct with which activation was first seen at $3 \mathrm{~h}$ followed by an inhibition at $6 \mathrm{~h}$. $\mathrm{UreB}^{-}$and $\mathrm{FlaA}^{-}$ isogenic mutants had no effect. Infection with $\mathrm{CagA}^{-}$resulted in $50 \%$ inhibition of the $-223 /-1$ construct at $1 \mathrm{~h}$ infection. In AGS cells, a transient inhibitory effect of ATCC 43504 strain was found on the proximal promoter (-223/-1) at $1 \mathrm{~h}$ infection (75\% inhibition) and on the distal promoter (-2044/-1117) at $3 \mathrm{~h}\left(50 \%\right.$ inhibition). $\mathrm{FlaA}^{-}$and $\mathrm{CagA}^{-}$both induced activation of the distal promoter (-1329/-1117) at $1 \mathrm{~h}$ and $3 \mathrm{~h}$ infection, respectively. These effects were lost when using the -2044/-1117 deletion mutant indicating that FlaA and CagA responsive elements are present within the $-1329 /-1117$ of $M U C 5 B$ distal promoter. UreB ${ }^{-}$induced a 3fold transactivating effect of the $-2044 /-1117$ deletion mutant at $6 \mathrm{~h}$ infection that was lost with the $-1329 /-1117$ mutant indicating that UreB responsive elements are present within the 2044/-1330 region of $M U C 5 B$ distal promoter.

\section{Effects of Hp infection on cytokines and NF- $\kappa$ B expression in KATO-III and AGS cells}

In order to correlate mucin gene altered expression after gastric cell infection by Hp and virulence factors to known pro-inflammatory cytokines and signaling pathway regulated by Hp, expression level of $I L-8, I L-1 \beta, I L-6, T N F-\alpha$ and $N F-\kappa B$ mRNA were measured. Our results indicate that $I L-8$ and $T N F-\alpha$ mRNA levels were increased in infected KATO-III cells as soon as $1 \mathrm{~h}$ (Fig. 5A). IL-6 mRNA was neither expressed nor up-regulated in these cells (data not shown). $I L-8$ induction by N6 wild-type strain seemed to be mediated by the urease factor since the activation was decreased when cells were infected with $\mathrm{UreB}^{-}$mutant. $T N F-\alpha$ mRNA was strongly induced by wild-type strains as early as $1 \mathrm{~h}$ infection. Early activation of 
$T N F$ - $\alpha$ by Hp seems also to be mediated by the urease factor since $T N F$ - $\alpha$ mRNA activation was postponed to $6 \mathrm{~h}$ infection when using $\mathrm{UreB}^{-}$mutant. $I L-1 \beta$ mRNA activation occurred at 3h infection with ATCC 43503 strain and at $1 \mathrm{~h}$ with N6 wild-type strain. IL-1 $\beta$ activation is also mediated by urease since the activation was strongly decreased as early as $1 \mathrm{~h}$ when using UreB $^{-}$isogenic mutant. $N F-\kappa B$ mRNA level was increased as soon as 1 h infection with N6 wild type strain and this effect was lost with virulence factors UreB. In AGS cells, Hp infection with both wild-type strains induced an early (1h) transient expression of $I L-8$ mRNA that was lost thereafter (Fig. 5B). The activation at $1 \mathrm{~h}$ was maintained with $\mathrm{FlaA}^{-}$mutant whereas it was lost with $\mathrm{UreB}^{-}$confirming the role of urease in mediating $I L-8$ activation by Hp. NF- $\kappa \mathrm{B}$ mRNA expression increased as of $3 \mathrm{~h}$ infection with both wild type strains and was maintained at $6 \mathrm{~h}$. This effect was mediated by UreB since infection with this deficient mutant did not show any induction of $N F-\kappa B$ expression. All the other cytokines studied (IL$1 \beta$, IL-6 and TNF- $\alpha$ ) were neither expressed nor induced in these cells (data not shown). Altogether these results indicate that Hp infection of KATO-III cells activates $I L-8, I L-1 \beta$ and $T N F-\alpha$ and $N F-\kappa B$ expression and that this process is mediated by the UreB virulence factor. In AGS cells, the same mechanism involving UreB was found for $I L-8$ and $N F-\kappa B$.

\section{Role of NF- $\kappa \mathrm{B}$ in the urease- and flagellin-mediated transcription of $M U C 5 A C$}

Since we showed in this report that, (i) urease and flagellin alter mucin gene transcription, (ii) urease- and flagellin-response elements are present within MUC5AC promoter, and (iii) UreB mediates activation of cytokines and NF- $\kappa \mathrm{B}$, we undertook to establish a link between $\mathrm{NF}-\kappa \mathrm{B}$ and $M U C 5 A C$ regulation by urease and flagellin. To this aim, co-transfection experiments were performed in the presence of the promoter of MUC5AC and a NF- $\kappa \mathrm{B}$ expression vector encoding the p65 transactivating subunit of NF- $\kappa \mathrm{B}$. In KATO-III cells, no effect was observed with $\mathrm{UreB}^{-}$whereas activation of -202/-1 MUC5AC promoter 
region (4.2 fold increase) was found at $6 \mathrm{~h}$ with $\mathrm{FlaA}^{-}$(Fig. 6, upper panel). In UreB-infected AGS cells (Fig. 6, lower panel), overexpression of NF- $\kappa \mathrm{B}$ p65 subunit led to the activation of the -1366/-1 region of MUC5AC promoter (2 fold, black bars). This effect was lost when using the $-202 /-1$ fragment (white bars). This result indicates that the effects of UreB- on MUC5AC promoter activity in AGS cells may be mediated by NF- $\kappa \mathrm{B}$. 


\section{Discussion}

Helicobacter pylori, a gram-negative bacterium, has been implicated as a causative agent for gastritis, peptic ulcer and gastric carcinoma. Byrd et al. recently showed that Hpinduced gastritis is characterized by a decrease of MUC5AC production and an aberrant expression of MUC6 by the surface epithelial cells (MUC6 is normally expressed in gastric glands) $[16,18]$. Moreover, Hp-infected preneoplastic and neoplastic gastric mucosae also show altered expression of MUC2, MUC5AC and MUC6 mucins [17].

However, while extensive characterization of $\mathrm{Hp}$ adhesins and MUC5AC oligosaccharidic structures involved in Hp-MUC5AC interaction has been described in the literature [12-15, 19], nothing is known about the molecular mechanisms driven by Hp that regulate mucin gene expression in the stomach. We therefore undertook to study the effects of Hp on mucin gene expression at the transcriptional level in KATO-III and AGS gastric cancer cells. We focused our work on two virulence factors involved in Hp colonization of the stomach, that is urease and flagellin and a virulence factor involved in injury genesis, CagA. Urease produces abundant amounts of ammonia and flagellin promotes Hp motility. Kawano et al. showed that ammonia chronically administrated orally in rats leads to changes in gastric mucosal structures and functions and induces a dose- and time-dependent decrease of intracellular mucin [30]. No relation between Hp flagella and mucin expression has been studied so far. Interestingly, some data obtained in the lung are in favor of a role for flagellin as a mucin regulator since it was shown that Pseudomonas aeruginosa flagellin induces transcription and expression of the mucin MUC2 after binding to lung epithelial cells via the membrane glycolipid ASGM1 [31]. The presence of $\operatorname{cagA}$ is statistically associated with duodenal ulceration, gastric mucosal atrophy and gastric cancer. The precise functions of the cag PAI, that confers inflammatory power to the strain, are still unknown. CagA is able to modulate the activity of MAP kinases and consequently the cellular pathways which regulate 
cell proliferation, cell differentiation, apoptosis, reaction to stress and inflammatory responses. Activation of MAP kinases by Hp cag PAI positive strains [32] may be crucial in developing gastroduodenal inflammation and alteration of mucin gene expression especially since MAP kinases are also known to regulate mucin gene expression [33, 34].

In this report, we show for the first time that urease mediates down-regulation of $M U C 5 A C$ transcription in gastric cancer cells in a cell-specific manner. We also have identified UreB-responsive elements in the $-486 /-1$ and -1366/-202 regions of MUC5AC promoter in KATO-III and AGS cells, respectively. These results suggest that MUC5AC promoter contain UreB-responsive elements that are cell-specific. FlaA, another virulence factor involved in Hp motility and colonization, did not alter mucin gene mRNA levels in either cell line. However, FlaA-responsive elements were found in MUC2 and MUC5AC promoters, which suggests that in another cellular context FlaA may alter mucin gene expression. In AGS cells, mucin gene mRNA levels were not altered after Hp infection. This is most likely the consequence of methylation as we had previously shown that $11 \mathrm{p} 15$ mucin genes are methylated in that cell line [35]. Despite that, AGS cells proved to be a great model to study the regulation of mucin genes at the promoter level and identify Hp-responsive elements. Indeed in these cells, we have identified UreB- and FlaA-responsive elements in the promoters of $M U C 2, M U C 5 A C$ and $M U C 5 B$ and CagA-responsive elements in the promoters of $M U C 2$ and $M U C 5 B$. Since, these two genes are expressed in the stomach during the precancerous step of intestinal metaplasia [17], it is an argument in favor of an association between CagA presence in the stomach and severity of the disease. These results also suggest that the different virulence factors of $\mathrm{Hp}$ act chronologically during infection and development of the disease. Moreover, urease- and flagellin-mediated inhibition of $M U C 5 A C$ gene expression (this report) is well correlated with the decrease of MUC5AC apomucin observed in the stomach [16-18], which may favor mucus penetration by Hp during stomach colonization. After anchoring of the bacteria on gastric mucosa, which persists without 
adapted antibiotic treatment, the other virulence factors then become effective and create mucosal injuries. CagA, could be one of the numerous factors participating to the gastric cancer development by altering $M U C 2$ and $M U C 5 B$ gene expression.

Previous data have shown that urease is a proinflammatory molecule that up-regulates production of potent proinflammatory cytokines [36] and most likely that effect is mediated by $\mathrm{NF}-\kappa \mathrm{B}$ transcription factor $[37,38]$. Moreover, NF- $\kappa \mathrm{B}$ has already been shown to upregulate $M U C 2$ and $M U C 5 A C$ transcription in cultured airway epithelial cells and bronchial explants after cell infection by the gram-negative bacterium Pseudomonas aeruginosa [33, 39]. In that case, the bacteria adheres to the cell and then activates NF- $\kappa \mathrm{B}$ pathway via lipopolysaccharide binding to a receptor yet to be characterized [40]. Two $\kappa \mathrm{B}$ cis-elements are present in MUC5AC promoter at -958/-949 and -227/-215 [41] that could be involved in the response to urease via NF- $\mathrm{BB}$ in AGS cells and lead to down regulation of MUC5AC promoter activity. In KATO-III cells, this phenomenon is NF- $\kappa \mathrm{B}$-independent. Thus, it seems that Hp uses different cell-specific signaling pathways to regulate $M U C 5 A C$ expression in gastric epithelial cells.

The three wild type strains of Hp used in this work induced a transient activation of MUC2, MUC5AC and MUC6 mucin gene expression at $1 \mathrm{~h}$ infection in KATO-III cells. There was no effect on $M U C 5 B$ expression. The reversal after $3 \mathrm{~h}$ is most likely due to the fact that enough mRNA was produced following infection and that the cell has enough then to express and secrete mucins. Moreover, it has already been shown in our laboratory and it is known that mRNA encoding secreted mucins have quite a long half-life [42] and thus as mentioned above, a cell has enough mRNA to express a secreted mucin and does not need transcription to go on for long periods.

This early response leading to the up-regulation of mucin gene expression is to be correlated with early response of the cells to the infection by up-regulating the expression of IL- 8 chemokine, IL- $1 \beta$ and TNF- $\alpha$ pro-inflammatory cytokines. This indicates that mucins 
can be considered as an early response of the cell to protect itself against bacterial injury. Hp infection of the stomach is associated with the development of inflammation [2]. Virulence factors of $\mathrm{Hp}$ participate in maintaining that inflammatory state $[36,43]$. We thus hypothesize that gastric cells may, in an autocrine system, respond to Hp infection by up-regulating a panel of chemokines and pro-inflammatory cytokines in order to attract inflammatory cells but also to express mucins to protect themselves against injury. Indeed the mucus secretion is $\underline{\text { the first protective line of mucosal surfaces against pathogens and irritants by providing an }}$ efficient mucus layer with specific rheological properties [44]. Mucin secretion in the stomach, by modifying the gastric environment for colonization, may thus play a role of antibiotic against the bacteria [45-47], increase immunoreactivity in the mucosa [48], but also inhibit H. pylori proliferation [49]. In a healthy adult, this autocrine system would suffice to $\underline{\text { trap and eradicate the bacteria, whereas in other situations such as chronic or more severe }}$ $\underline{\text { inflammation and more vulnerable patients mucin secretion would be either not sufficient or }}$ worse used by the bacteria to adhere, develop and in some cases cause gastric neoplasia $\underline{\text { leading to cancer. }}$

In conclusion, we have shown that Helicobacter pylori regulates mucin gene expression at the transcriptional level in gastric cancer cells. Hp-, urease-, flagellin- and CagA-responsive elements were found in $M U C 2, M U C 5 A C$ and $M U C 5 B$ promoters and urease-mediated inhibition of MUC5AC in KATO-III cells is independent of $\mathrm{NF}-\kappa \mathrm{B}$ activation. Finally, concomitant early up-regulation of mucin genes and pro-inflammatory cytokines is in favor of autocrine systems activated by gastric cells in response to $\mathrm{Hp}$ infection. 


\section{Acknowledgements}

We would like to thank Danièle Petitprez for her excellent technical help and Dr Agnès Labigne for the gift of the $H$. pylori mutated strains (Institut Pasteur, Pathogénie bactérienne des muqueuses, Paris). This work was supported by the European Regional Development Fund (I. Van Seuningen). This work received the Janssen-Cylen Award at the GEFH (Groupe d'Etude Français des Helicobacter) Helicobacter pylori Day, Institut Pasteur, Paris, France. 


\section{Figure Legends}

Figure 1: Effect of Hp on 11p15 mucin gene expression in KATO-III cells. Expression of MUC2, MUC5AC, MUC5B and MUC6 mRNAs was evaluated by the means of RT-PCR after KATO-III cell infection with Hp wild-type strains (ATCC 43504, N6 and SS1) and N6 isogenic mutants (N6 $\mathrm{UreB}^{-}, \mathrm{N} \mathrm{FlaA}^{-}$and SS1 CagA-). $10 \mu 1$ of PCR products were loaded on a $1.5 \%$ agarose gel and electrophoresed in $1 \mathrm{X}$ TBE buffer containing ethidium bromide.

Figure 2: Regulation of $M U C 2$ promoter by $\mathrm{Hp}$ wild-type strains and $\mathrm{UreB}^{-}, \mathrm{FlaA}^{-}$and CagA $^{-}$isogenic mutants in KATO-III and AGS cells. Results are expressed as fold induction of luciferase activity of the promoter constructs in infected cells with deficient mutants over activity in infected cells with wild-type strain $\left(\mathrm{UreB}^{-} / \mathrm{N} 6, \mathrm{FlaA}^{-} / \mathrm{N} 6, \mathrm{CagA}^{-}\right.$ /SS1). The results are means +/- S.D. and represent three different experiments in triplicate for each fragment.

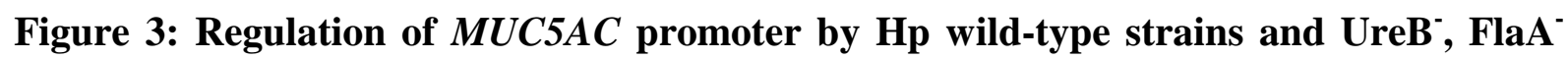
and $\mathrm{CagA}^{-}$isogenic mutants in KATO-III and AGS cells. Results are expressed as fold induction of luciferase activity of the promoter constructs in infected cells with deficient mutants over activity in infected cells with wild-type strain $\left(\mathrm{UreB}^{-} / \mathrm{N} 6, \mathrm{FlaA}^{-} / \mathrm{N} 6, \mathrm{CagA}^{-}\right.$ /SS1). The results are means +/- S.D. and represent three different experiments in triplicate for each fragment.

Figure 4: Regulation of $M U C 5 B$ promoters by $\mathrm{Hp}$ wild-type strains and $\mathrm{UreB}^{-}$, $\mathrm{FlaA}^{-}$ and CagA $^{-}$isogenic mutants in KATO-III and AGS cells. Results are expressed as fold induction of luciferase activity of the promoter constructs in infected cells with deficient

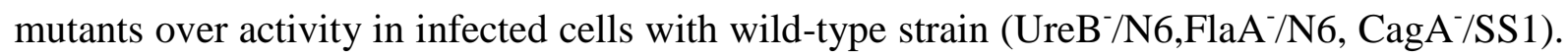


The results are means +/- S.D. and represent three different experiments in triplicate for each fragment.

Figure 5: Expression of cytokines and NF- $\kappa \mathrm{B}$ p65 subunit in Hp-infected gastric cancer cells by RT-PCR. Cells were treated for $1 \mathrm{~h}, 3 \mathrm{~h}$ or $6 \mathrm{~h}$ with $\mathrm{Hp}$ wild-type strains (ATCC 43504 or N6) or FlaA ${ }^{-}$and $\mathrm{UreB}^{-}$isogenic mutants. (A): KATO-III cells and (B): AGS cells. $10 \mu 1$ of the PCR products were loaded on a $1.5 \%$ agarose gel and electrophoresed in $1 \mathrm{X}$ TBE buffer containing ethidium bromide.

Figure 6: Role of NF- $\kappa \mathrm{B}$ on $M U C 5 A C$ promoter activity after Hp infection. Cotransfections studies were performed in KATO-III and AGS cells in the presence of pCMV4NF- $\kappa \mathrm{B}$ p65 expression vector encoding the transactivating subunit of NF- $\kappa \mathrm{B}$ and the pGL3MUC5AC deletion mutants covering either the -1366/-1 (black bars) or the -202/-1 (white bars) regions of the promoter. Co-transfections with empty vector pCMV4 was performed and luciferase value considered as 1 (Ref, gray bar). Cells were infected for $1 \mathrm{~h}$, $3 \mathrm{~h}$ or $6 \mathrm{~h}$ with $\mathrm{Hp}$ wild-type strain N6 or its isogenic deficient mutants for urease B and flagellin A. Results are expressed as fold induction of luciferase activity in infected cells with deficient mutants over activity in infected cells with wild-type strain ( $\mathrm{UreB}^{-} / \mathrm{N} 6$ or FlaA'/N6). The results are means +/- S.D. and represent three different experiments in triplicate for each fragment. 


\section{References}

1. Correa P. Helicobacter pylori as a pathogen and carcinogen. J Physiol Pharmacol. 1997 Sep;48 Suppl 4:19-24.

2. Dunn BE, Cohen H, Blaser MJ. Helicobacter pylori. Clin Microbiol Rev. 1997 Oct;10(4):720-41.

3. Peek RM, Jr., Blaser MJ. Helicobacter pylori and gastrointestinal tract adenocarcinomas. Nat Rev Cancer. 2002 Jan;2(1):28-37.

4. Barreto-Zuniga R, Maruyama M, Kato Y, Aizu K, Ohta H, Takekoshi T, et al. Significance of Helicobacter pylori infection as a risk factor in gastric cancer: serological and histological studies. J Gastroenterol. 1997 Jun;32(3):289-94.

5. Corfield AP, Carroll D, Myerscough N, Probert CS. Mucins in the gastrointestinal tract in health and disease. Front Biosci. 2001 Oct 1;6:D1321-57.

6. Hollingsworth MA, Swanson BJ. Mucins in cancer: protection and control of the cell surface. Nat Rev Cancer. 2004 Jan;4(1):45-60.

7. Dekker J, Rossen JW, Buller HA, Einerhand AW. The MUC family: an obituary. Trends Biochem Sci. 2002 Mar;27(3):126-31.

8. Jonckheere N, Skrypek N, Frenois F, Van Seuningen I. Membrane-bound mucin modular domains: from structure to function. Biochimie. 2012 Nov 20.

9. Buisine MP, Devisme L, Maunoury V, Deschodt E, Gosselin B, Copin MC, et al. Developmental mucin gene expression in the gastroduodenal tract and accessory digestive glands. I. Stomach. A relationship to gastric carcinoma. J Histochem Cytochem. 2000 Dec;48(12):1657-66.

10. Teixeira A, David L, Reis CA, Costa J, Sobrinho-Simoes M. Expression of mucins (MUC1, MUC2, MUC5AC, and MUC6) and type 1 Lewis antigens in cases with and without Helicobacter pylori colonization in metaplastic glands of the human stomach. J Pathol. 2002 May;197(1):37-43.

11. Allen A, Newton J, Oliver L, Jordan N, Strugala V, Pearson JP, et al. Mucus and H. pylori. J Physiol Pharmacol. 1997 Sep;48(3):297-305.

12. Kocer B, Ulas M, Ustundag Y, Erdogan S, Karabeyoglu M, Yldrm O, et al. A confirmatory report for the close interaction of Helicobacter pylori with gastric epithelial MUC5AC expression. J Clin Gastroenterol. 2004 Jul;38(6):496-502.

13. Linden SK, Wickstrom C, Lindell G, Gilshenan K, Carlstedt I. Four modes of adhesion are used during Helicobacter pylori binding to human mucins in the oral and gastric niches. Helicobacter. 2008 Apr;13(2):81-93.

14. Van de Bovenkamp JH, Mahdavi J, Korteland-Van Male AM, Buller HA, Einerhand AW, Boren T, et al. The MUC5AC glycoprotein is the primary receptor for Helicobacter pylori in the human stomach. Helicobacter. 2003;8(5):521-32.

15. Magalhaes A, Reis CA. Helicobacter pylori adhesion to gastric epithelial cells is mediated by glycan receptors. Braz J Med Biol Res. 2010 Jul;43(7):611-8.

16. Byrd JC, Yan P, Sternberg L, Yunker CK, Scheiman JM, Bresalier RS. Aberrant expression of gland-type gastric mucin in the surface epithelium of Helicobacter pyloriinfected patients. Gastroenterology. 1997 Aug;113(2):455-64.

17. Babu SD, Jayanthi V, Devaraj N, Reis CA, Devaraj H. Expression profile of mucins (MUC2, MUC5AC and MUC6) in Helicobacter pylori infected pre-neoplastic and neoplastic human gastric epithelium. Mol Cancer. 2006;5:10.

18. Byrd JC, Yunker CK, Xu QS, Sternberg LR, Bresalier RS. Inhibition of gastric mucin synthesis by Helicobacter pylori. Gastroenterology. 2000 Jun;118(6):1072-9. 
19. Morgenstern S, Koren R, Moss SF, Fraser G, Okon E, Niv Y. Does Helicobacter pylori affect gastric mucin expression? Relationship between gastric antral mucin expression and H. pylori colonization. Eur J Gastroenterol Hepatol. 2001 Jan;13(1):19-23.

20. Dunn BE, Phadnis SH. Structure, function and localization of Helicobacter pylori urease. Yale J Biol Med. 1998 Mar-Apr;71(2):63-73.

21. O'Toole PW, Lane MC, Porwollik S. Helicobacter pylori motility. Microbes Infect. 2000 Aug;2(10):1207-14.

22. Backert S, Ziska E, Brinkmann V, Zimny-Arndt U, Fauconnier A, Jungblut PR, et al. Translocation of the Helicobacter pylori CagA protein in gastric epithelial cells by a type IV secretion apparatus. Cell Microbiol. 2000 Apr;2(2):155-64.

23. Perrais M, Pigny P, Buisine MP, Porchet N, Aubert JP, Van Seuningen-Lempire I. Aberrant expression of human mucin gene MUC5B in gastric carcinoma and cancer cells. Identification and regulation of a distal promoter. J Biol Chem. 2001 May 4;276(18):1538696.

24. Ferrero RL, Cussac V, Courcoux P, Labigne A. Construction of isogenic ureasenegative mutants of Helicobacter pylori by allelic exchange. J Bacteriol. 1992 Jul;174(13):4212-7.

25. Suerbaum S, Josenhans C, Labigne A. Cloning and genetic characterization of the Helicobacter pylori and Helicobacter mustelae flaB flagellin genes and construction of $\mathrm{H}$. pylori flaA- and flaB-negative mutants by electroporation-mediated allelic exchange. $\mathrm{J}$ Bacteriol. 1993 Jun;175(11):3278-88.

26. Chevalier C, Thiberge JM, Ferrero RL, Labigne A. Essential role of Helicobacter pylori gamma-glutamyltranspeptidase for the colonization of the gastric mucosa of mice. Mol Microbiol. 1999 Mar;31(5):1359-72.

27. Lee A, O'Rourke J, De Ungria MC, Robertson B, Daskalopoulos G, Dixon MF. A standardized mouse model of Helicobacter pylori infection: introducing the Sydney strain. Gastroenterology. 1997 Apr;112(4):1386-97.

28. Perrais M, Pigny P, Copin MC, Aubert JP, Van Seuningen I. Induction of MUC2 and MUC5AC mucins by factors of the epidermal growth factor (EGF) family is mediated by EGF receptor/Ras/Raf/extracellular signal-regulated kinase cascade and Sp1. J Biol Chem. 2002 Aug 30;277(35):32258-67.

29. Van Seuningen I, Perrais M, Pigny P, Porchet N, Aubert JP. Sequence of the 5'flanking region and promoter activity of the human mucin gene MUC5B in different phenotypes of colon cancer cells. Biochem J. 2000 Jun 15;348 Pt 3:675-86.

30. Kawano S, Tsujii M, Fusamoto H, Sato N, Kamada T. Chronic effect of intragastric ammonia on gastric mucosal structures in rats. Dig Dis Sci. 1991 Jan;36(1):33-8.

31. McNamara N, Khong A, McKemy D, Caterina M, Boyer J, Julius D, et al. ATP transduces signals from ASGM1, a glycolipid that functions as a bacterial receptor. Proc Natl Acad Sci U S A. 2001 Jul 31;98(16):9086-91.

32. Meyer-ter-Vehn T, Covacci A, Kist M, Pahl HL. Helicobacter pylori activates mitogen-activated protein kinase cascades and induces expression of the proto-oncogenes cfos and c-jun. J Biol Chem. 2000 May 26;275(21):16064-72.

33. Basbaum C, Lemjabbar H, Longphre M, Li D, Gensch E, McNamara N. Control of mucin transcription by diverse injury-induced signaling pathways. Am J Respir Crit Care Med. 1999 Nov;160(5 Pt 2):S44-8.

34. Van Seuningen I, Pigny P, Perrais M, Porchet N, Aubert JP. Transcriptional regulation of the $11 \mathrm{p} 15$ mucin genes. Towards new biological tools in human therapy, in inflammatory diseases and cancer? Front Biosci. 2001 Oct 1;6:D1216-34.

35. Vincent A, Perrais M, Desseyn JL, Aubert JP, Pigny P, Van Seuningen I. Epigenetic regulation (DNA methylation, histone modifications) of the $11 \mathrm{p} 15$ mucin genes (MUC2, MUC5AC, MUC5B, MUC6) in epithelial cancer cells. Oncogene. 2007 Oct 4;26(45):656676. 
36. Harris PR, Mobley HL, Perez-Perez GI, Blaser MJ, Smith PD. Helicobacter pylori urease is a potent stimulus of mononuclear phagocyte activation and inflammatory cytokine production. Gastroenterology. 1996 Aug;111(2):419-25.

37. Keates S, Hitti YS, Upton M, Kelly CP. Helicobacter pylori infection activates NFkappa B in gastric epithelial cells. Gastroenterology. 1997 Oct;113(4):1099-109.

38. van Den Brink GR, ten Kate FJ, Ponsioen CY, Rive MM, Tytgat GN, van Deventer SJ, et al. Expression and activation of NF-kappa B in the antrum of the human stomach. J Immunol. 2000 Mar 15;164(6):3353-9.

39. Dohrman A, Miyata S, Gallup M, Li JD, Chapelin C, Coste A, et al. Mucin gene (MUC 2 and MUC 5AC) upregulation by Gram-positive and Gram-negative bacteria. Biochim Biophys Acta. 1998 Apr 28;1406(3):251-9.

40. Li JD, Feng W, Gallup M, Kim JH, Gum J, Kim Y, et al. Activation of NF-kappaB via a Src-dependent Ras-MAPK-pp90rsk pathway is required for Pseudomonas aeruginosainduced mucin overproduction in epithelial cells. Proc Natl Acad Sci U S A. 1998 May 12;95(10):5718-23.

41. Li D, Gallup M, Fan N, Szymkowski DE, Basbaum CB. Cloning of the aminoterminal and 5'-flanking region of the human MUC5AC mucin gene and transcriptional upregulation by bacterial exoproducts. J Biol Chem. 1998 Mar 20;273(12):6812-20.

42. Debailleul V, Laine A, Huet G, Mathon P, d'Hooghe MC, Aubert JP, et al. Human mucin genes MUC2, MUC3, MUC4, MUC5AC, MUC5B, and MUC6 express stable and extremely large mRNAs and exhibit a variable length polymorphism. An improved method to analyze large mRNAs. J Biol Chem. 1998 Jan 9;273(2):881-90.

43. Harris PR, Weber HC, Wilcox CM, Jensen RT, Smith PD. Cytokine gene profile in gastric mucosa in Helicobacter pylori infection and Zollinger-Ellison syndrome. Am J Gastroenterol. 2002 Feb;97(2):312-8.

44. Johansson ME, Sjovall H, Hansson GC. The gastrointestinal mucus system in health and disease. Nat Rev Gastroenterol Hepatol. 2013 Mar 12. doi: 10.1038/nrgastro.2013.35

45. Fukuda M, Kawakubo M, Ito Y, Kobayashi M, Lee H, Nakayama J. Assay of human gastric mucin as a natural antibiotic against Helicobacter pylori. Methods Enzymol. 2006;415:164-79.

46. Kawakubo M, Ito Y, Okimura Y, Kobayashi M, Sakura K, Kasama S, et al. Natural antibiotic function of a human gastric mucin against Helicobacter pylori infection. Science. 2004 Aug 13;305(5686):1003-6.

47. Kobayashi M, Lee H, Nakayama J, Fukuda M. Roles of gastric mucin-type O-glycans in the pathogenesis of Helicobacter pylori infection. Glycobiology. 2009 May;19(5):453-61.

48. Matsuzwa M, Ota H, Hayama M, Zhang MX, Sano K, Honda T, et al. Helicobacter pylori infection up-regulates gland mucous cell-type mucins in gastric pyloric mucosa. Helicobacter. 2003 Dec;8(6):594-600.

49. Skoog EC, Sjoling A, Navabi N, Holgersson J, Lundin SB, Linden SK. Human gastric mucins differently regulate Helicobacter pylori proliferation, gene expression and interactions with host cells. PLoS One. 2012;7(5):e36378. 


\begin{tabular}{|c|c|c|c|}
\hline $\begin{array}{l}\text { Target } \\
\text { gene }\end{array}$ & Nucleotide sequence $\left(5^{\prime} \rightarrow 3^{\prime}\right)$ & $\begin{array}{l}\text { Size of PCR } \\
\text { product (bp) }\end{array}$ & $\begin{array}{c}\text { Annealing } \\
\text { temperature } \\
\left({ }^{\circ} \mathrm{C}\right)\end{array}$ \\
\hline 18S RNA & $\begin{array}{l}\text { S: GGA CCA GAG GCA AAG CAT TTG CC } \\
\text { AS: TCA ATC TCG GGT GGC TGA ACG C }\end{array}$ & 480 & 64 \\
\hline IL-1 $\beta$ & $\begin{array}{l}\text { S : ATT CTG ATG AGC AAC CGC TT } \\
\text { AS: GCA CAC CAG TCC AAA TTG AA }\end{array}$ & 156 & 55 \\
\hline IL-6 & $\begin{array}{l}\text { S: GGG AAG CTT GCT ATG AAC TCC TCC TCC AGA } \\
\text { AS : GGG GAA TTC ATG CTA CAT TTG CCG AAG AGC }\end{array}$ & 639 & 68 \\
\hline IL-8 & $\begin{array}{l}\text { S: AAG GAA CCA TCT CAC TG } \\
\text { AS: GAT TCT TGG ATA CCA CAG AG }\end{array}$ & 352 & 50 \\
\hline $\mathrm{NF}-\kappa \mathrm{B}$ & $\begin{array}{l}\text { S: CTG CCG AGC TCA AGA TCT GCC GAG TAA AC } \\
\text { AS : GGA GGA GTC CGG AAC ACA ATG GCC ACT TGC C }\end{array}$ & 196 & 69 \\
\hline TNF- $\alpha$ & $\begin{array}{l}\text { S: CAG AGG GAA GAG TTC CCC AG } \\
\text { AS: CCT TGG TCT GGT AGG AGA CG }\end{array}$ & 325 & 61 \\
\hline
\end{tabular}

Table I: Sequences of the pairs of primers used in RT-PCR experiments to study the expression of the proinflammatory cytokines (IL-1 $\beta$, IL-6, IL-8, TNF- $\alpha$ ) and transcription factor NF- $\kappa$ B. S: sense orientation, AS: antisense orientation. 
Figure 1 : Perrais et al.

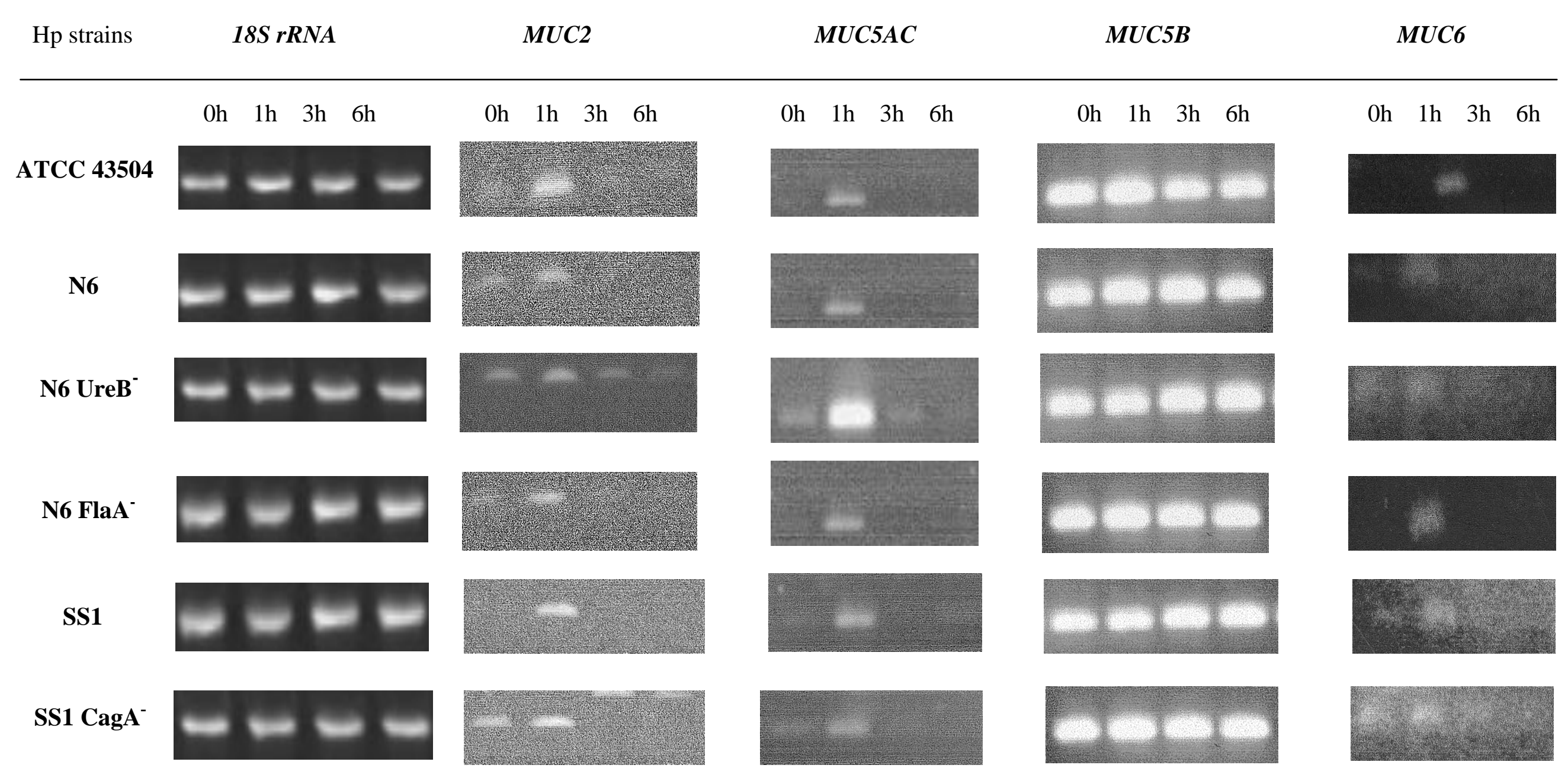


Figure 2 : Perrais et al.

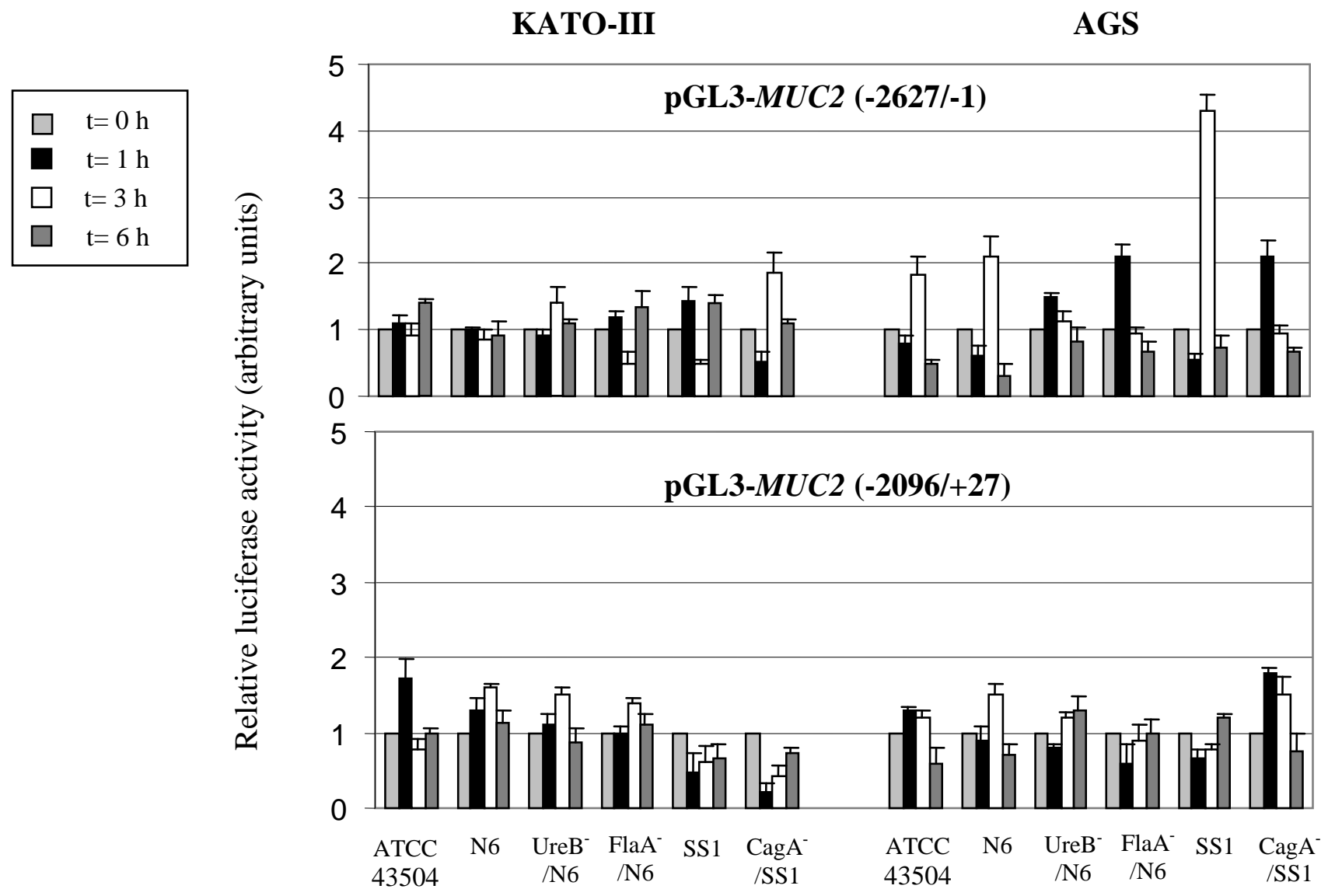


Figure 3 : Perrais et al.

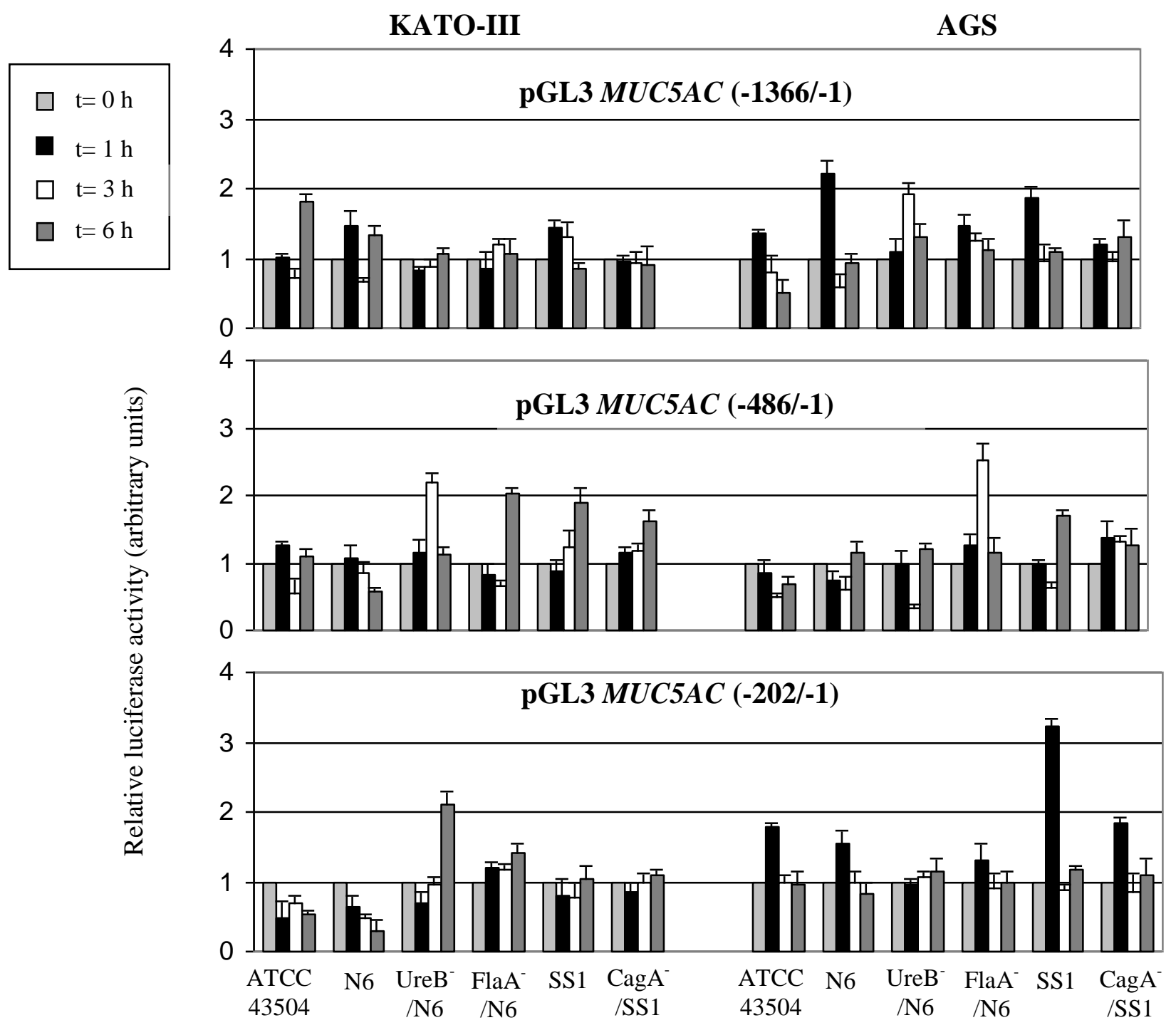


Figure 4 : Perrais et al.

KATO-III

AGS

$\square \mathrm{t}=0 \mathrm{~h}$
$\square \mathrm{t}=1 \mathrm{~h}$
$\square \mathrm{t}=3 \mathrm{~h}$
$\square \mathrm{t}=6 \mathrm{~h}$

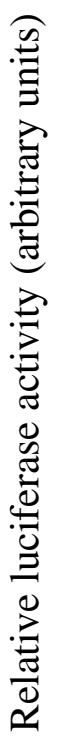

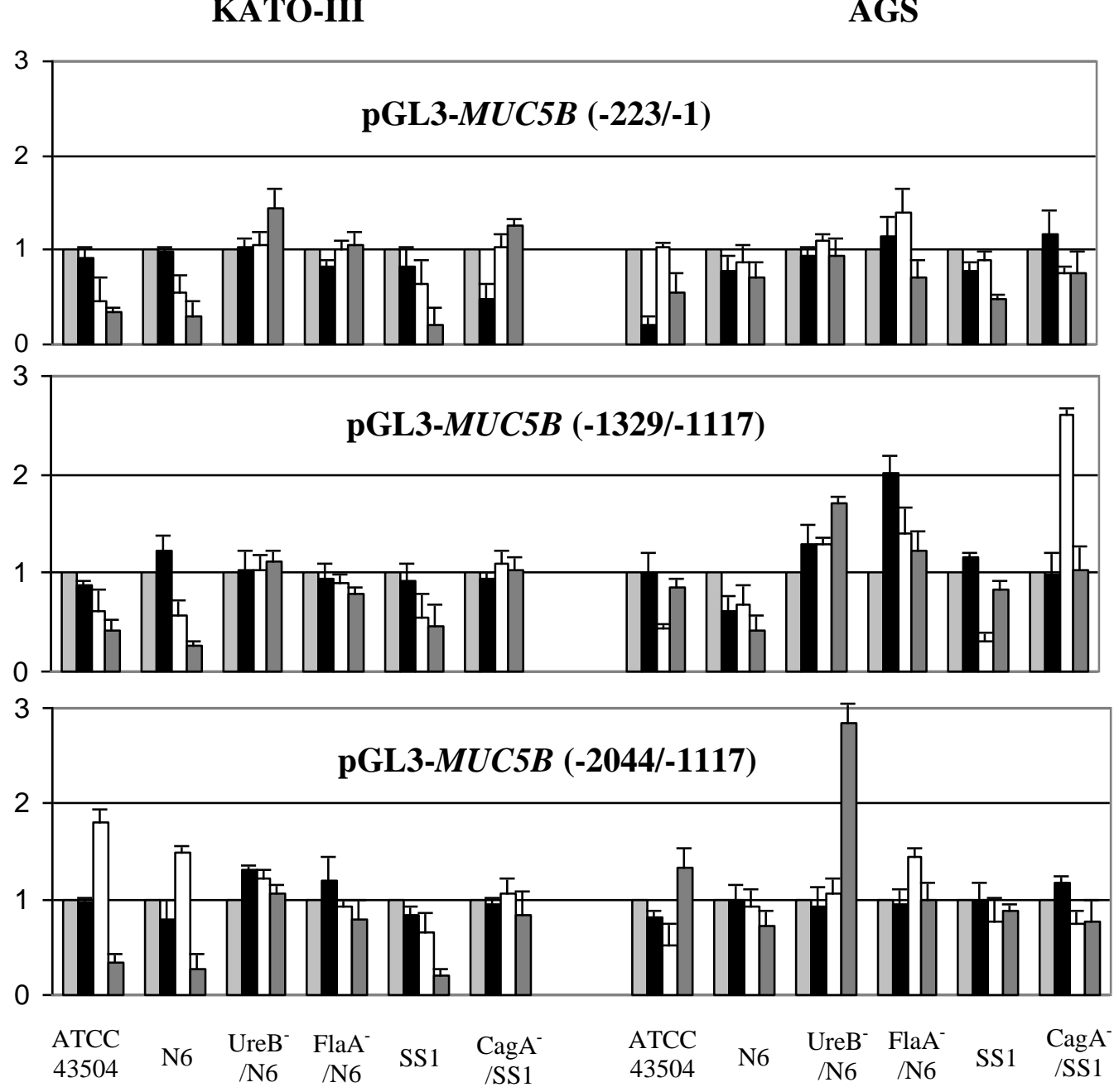



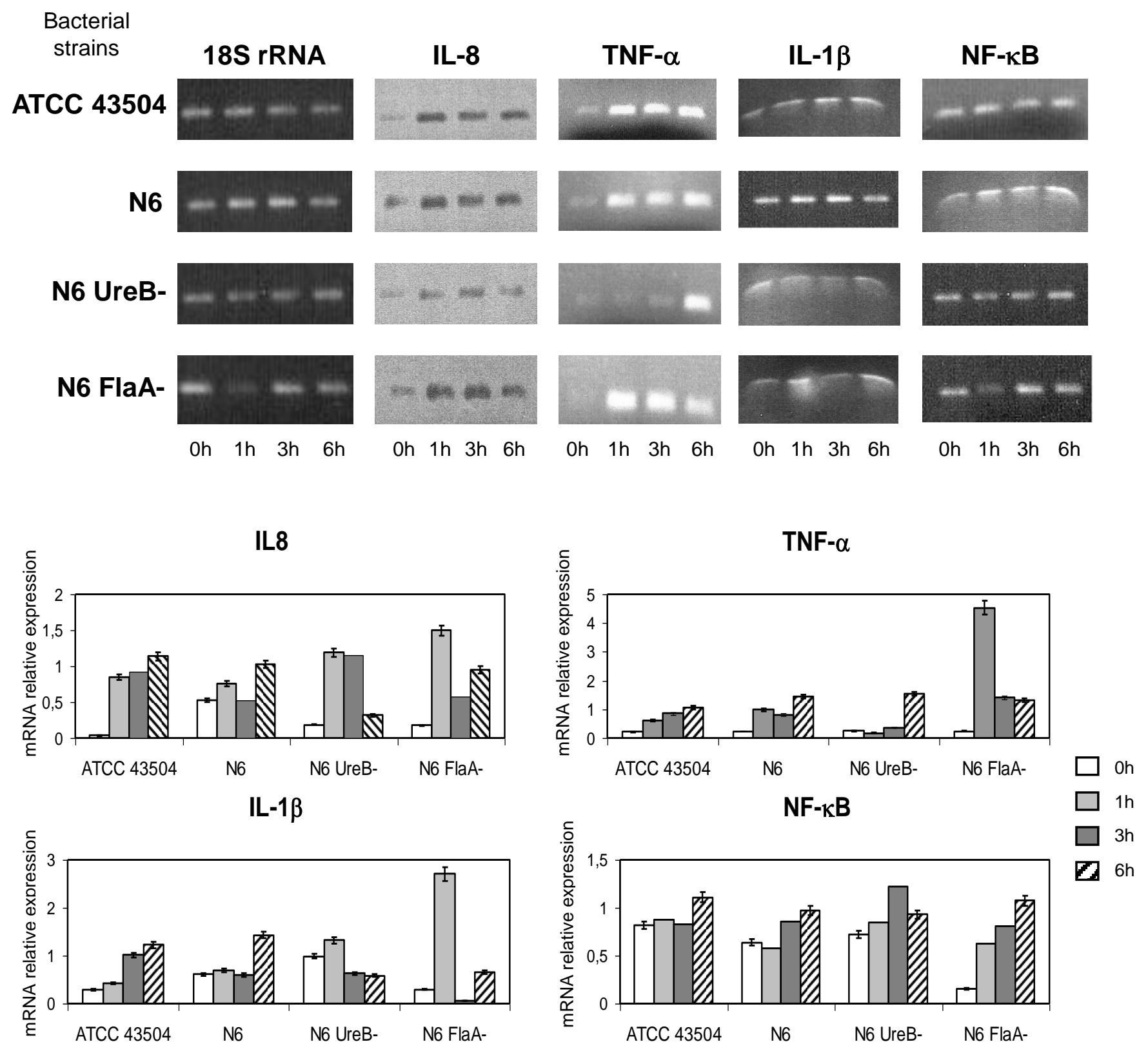
Figure 5B : Perrais et al.
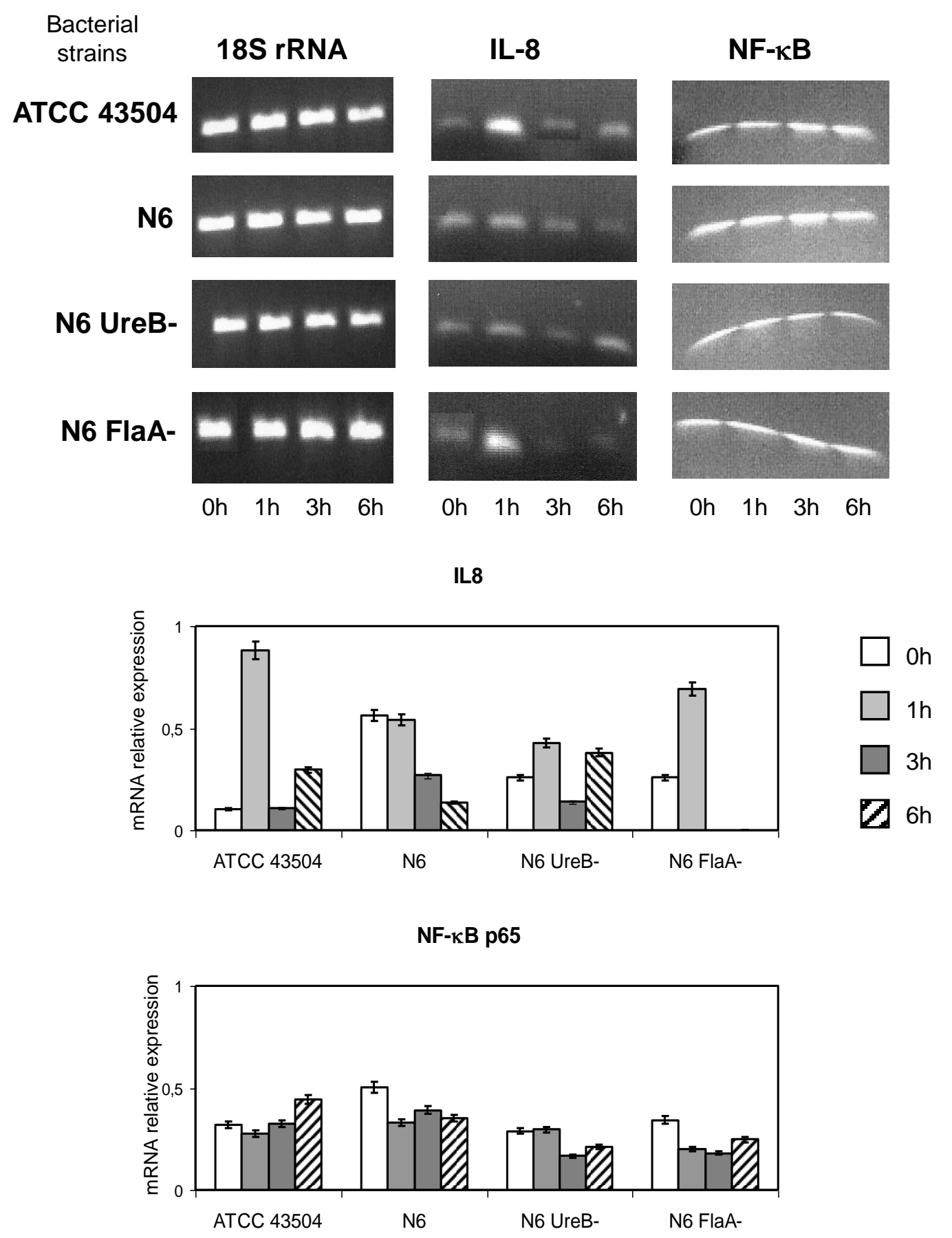
Figure 6 : Perrais et al.

\section{KATO-III}

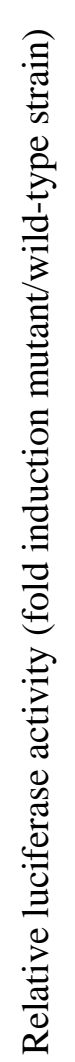
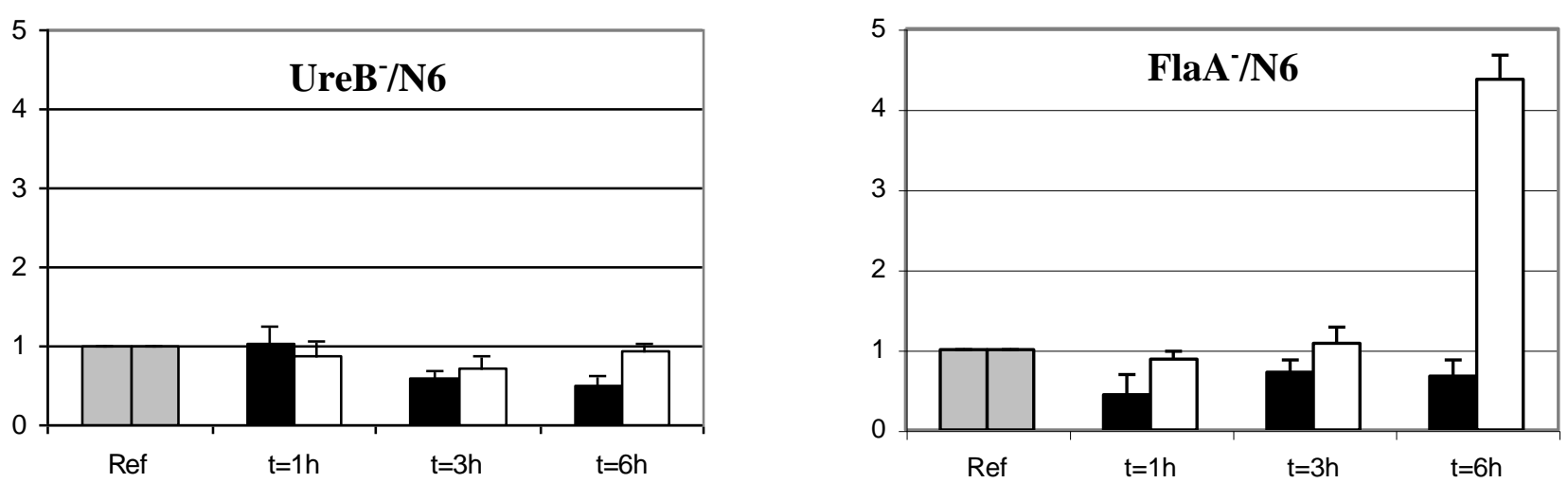

\section{AGS}
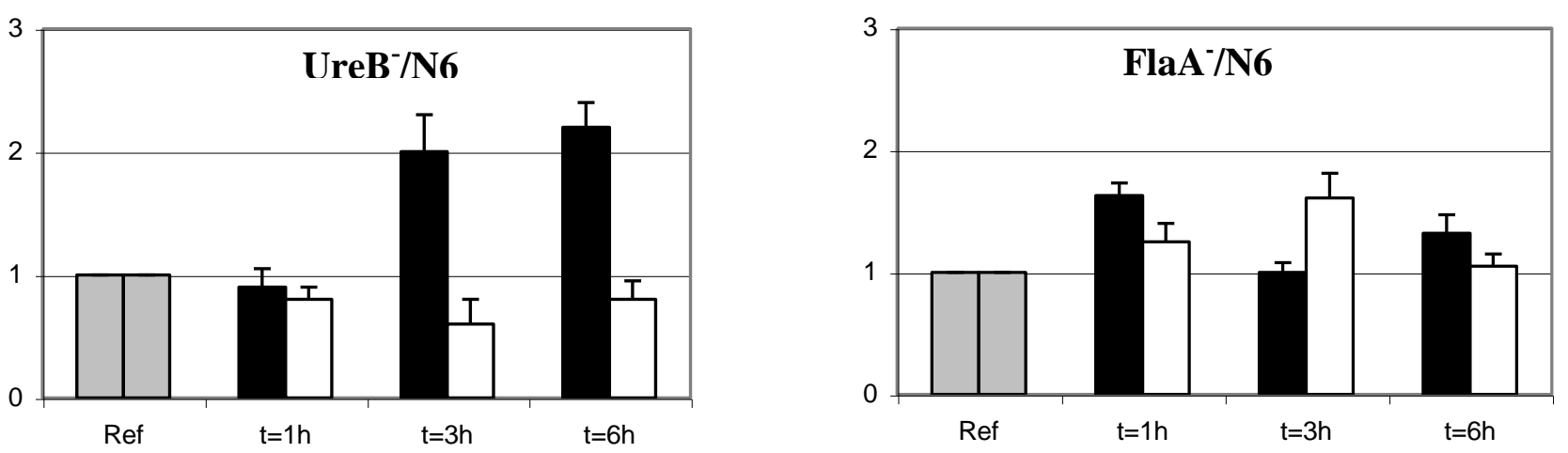
Helicobacter pylori $(\mathrm{Hp})$ interacts with gastric mucus gel and alter mucin gene expression. We show that Hp alters 11p15 mucin gene transcription and that MUC5AC downregulation is mediated by urease. 


\section{Prerequisites for Publication}

The Editors of Gastric Cancer receive and review manuscripts on the following conditions.

1. The contents have not been published elsewhere.

2. The manuscript is not under consideration for publication elsewhere.
3. All the authors had a significant part in the work and approved the final version of the manuscript.

4. Investigations in humans are in accordance with the ethical standards of the responsible committee (institutional or regional) or with the Helsinki Declaration.

5. Studies of animal experiments include a statement in the Materials section that all animals received humane care in compliance with the guidelines of the authors' institution or the National Research Council's criteria (NIH publication No. 86-23).

\section{Certification Form - to be submitted with manuscript}

\section{Gastric Cancer}

Manuscript title: Helicobacter pufori ureare aud flagellin alter mucin gente expussion in human gaskic cancer cells.

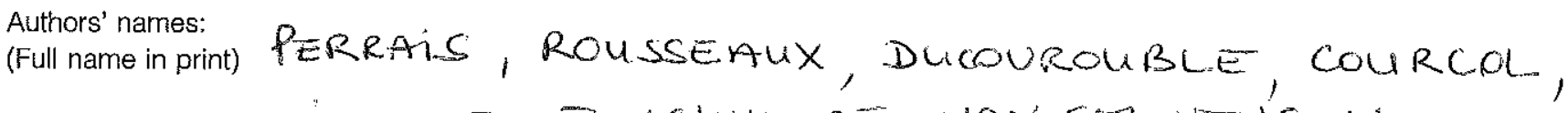
VINCENT, JONCKHEERE, VAN SBLNDNGEN

I (We) certify that the work submitted herewith is in full accordance with the above conditions set forth in the "Prerequisites for Publication" in Gastric Cancer.

Signature (in order of the authors' list in the manuscript):

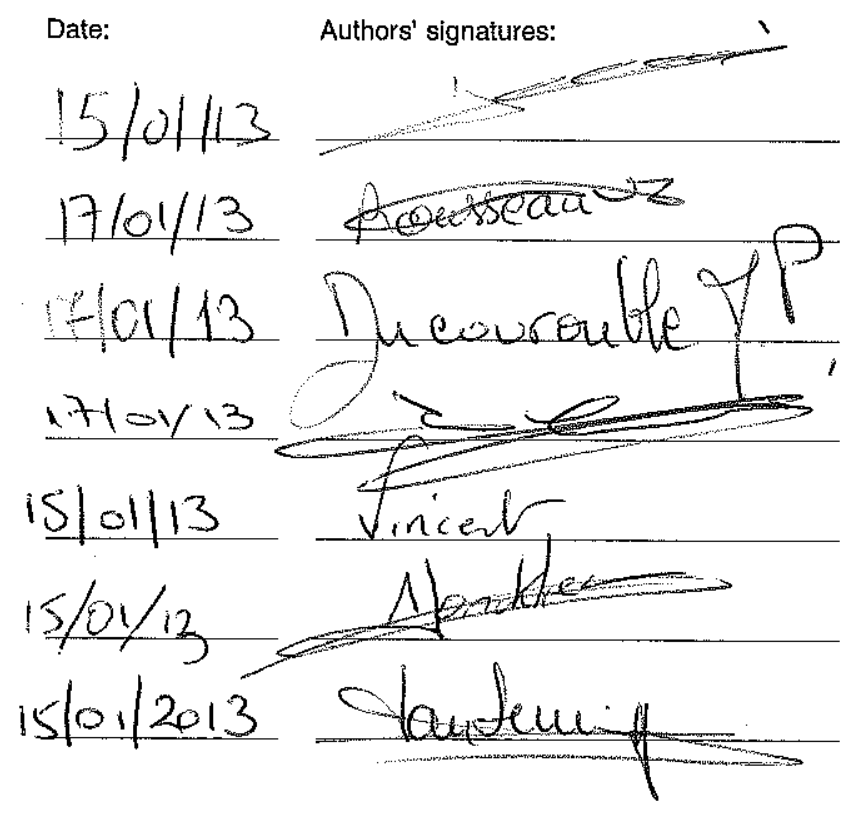

Date:

Authors' signatures:

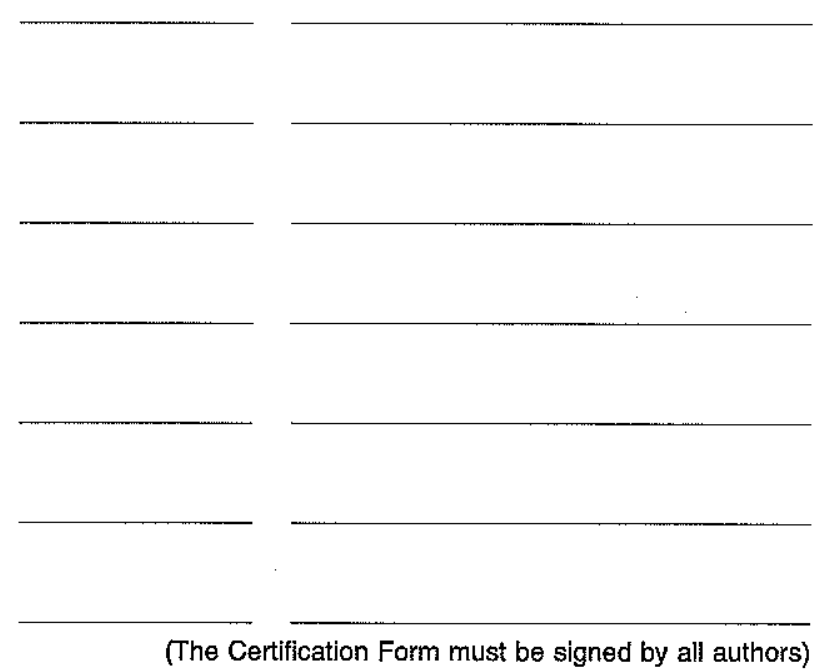

